\title{
RESEARCH
}

Open Access

\section{The TNF/TNFR2 signaling pathway is a key regulatory factor in endothelial progenitor cell immunosuppressive effect}

Sina Naserian ${ }^{1,2,3^{*}+}$ (D) Mohamed Essameldin Abdelgawad ${ }^{1,3,4+}$, Mazdak Afshar Bakshloo ${ }^{1}$, Guillaume Ha', Nassim Arouche ${ }^{1,3}$, José L. Cohen ${ }^{5,6}$, Benoît L. Salomon ${ }^{7}$ and Georges Uzan ${ }^{1,3^{*}}$

\begin{abstract}
Background: Endothelial progenitor cells (EPCS) are non-differentiated endothelial cells (ECs) present in blood circulation that are involved in neo-vascularization and correction of damaged endothelial sites. Since EPCs from patients with vascular disorders are impaired and inefficient, allogenic sources from adult or cord blood are considered as good alternatives. However, due to the reaction of immune system against allogenic cells which usually lead to their elimination, we focused on the exact role of EPCS on immune cells, particularly, T cells which are the most important cells applied in immune rejection. TNFa is one of the main activators of EPCs that recognizes two distinct receptors. TNFR1 is expressed ubiquitously and its interaction with TNFa leads to differentiation and apoptosis, whereas, TNFR2 is expressed predominantly on ECs, immune cells and neural cells and is involved in cell survival and proliferation. Interestingly, it has been shown that different immunosuppressive cells express TNFR2 and this is directly related to their immunosuppressive efficiency. However, little is known about immunological profile and function of TNFR2 in EPCs.

Methods: Using different in-vitro combinations, we performed co-cultures of ECs and T cells to investigate the immunological effect of EPCs on T cells. We interrupted in the TNFa/TNFR2 axis either by blocking the receptor using TNFR2 antagonist or blocking the ligand using T cells derived from TNFa KO mice.
\end{abstract}

Results: We demonstrated that EPCS are able to suppress T cell proliferation and modulate them towards less proinflammatory and active phenotypes. Moreover, we showed that TNFa/TNFR2 immune-checkpoint pathway is critical in EPC immunomodulatory effect.

Conclusions: Our results reveal for the first time a mechanism that EPCs use to suppress immune cells, therefore, enabling them to form new immunosuppressive vessels. Furthermore, we have shown the importance of TNFa/ TNFR2 axis in EPCS as an immune checkpoint pathway. We believe that targeting TNFR2 is especially crucial in cancer immune therapy since it controls two crucial aspects of tumor microenvironment: 1) Immunosuppression and 2) Angiogenesis.

Keywords: Endothelial Progenitor Cells (EPCs), Endothelial Colony Forming Cells (ECFCs), T cells, Immune regulation, Immune-checkpoint, TNFa/TNFR2 signaling pathway, Cancer immune therapy

\footnotetext{
*Correspondence: sina.naserian@inserm.fr; sina.naserian@cellmedex.com; georges.uzan@inserm.fr

†ina Naserian and Mohamed Essameldin Abdelgawad are co-first authors.

${ }^{1}$ INSERM UMR-S-MD 1197, Hôpital Paul Brousse, Villejuif, France

Full list of author information is available at the end of the article
}

C The Author(s). 2020 Open Access This article is licensed under a Creative Commons Attribution 4.0 International License, which permits use, sharing, adaptation, distribution and reproduction in any medium or format, as long as you give appropriate credit to the original author(s) and the source, provide a link to the Creative Commons licence, and indicate if changes were made. The images or other third party material in this article are included in the article's Creative Commons licence, unless indicated otherwise in a credit line to the material. If material is not included in the article's Creative Commons licence and your intended use is not permitted by statutory regulation or exceeds the permitted use, you will need to obtain permission directly from the copyright holder. To view a copy of this licence, visit http://creativecommons.org/licenses/by/4.0/ The Creative Commons Public Domain Dedication waiver (http://creativecommons.org/publicdomain/zero/1.0/) applies to the data made available in this article, unless otherwise stated in a credit line to the data. 


\section{Background}

Circulating Endothelial Progenitor Cells (EPCs) are nondifferentiated endothelial cells (ECs) first isolated from adult blood [1]. They are able to integrate vascular structures at damaged or neo-vascularization sites where they differentiate into mature ECs [2, 3], and are then crucial for maintaining the vascular integrity $[4,5]$. According to first colony appearance time, two distinct cell populations of EPCs have been identified: early EPCs or Colony Forming Unit-Endothelial Cells (CFU-ECs) and late EPCs or Endothelial Colony Forming Cells (ECFCs) [6]. In-vivo, ECFCs can form stable vessels through incorporating into vascular networks [7-9]. Therefore, ECFCs are accepted as true EPCs progeny expressing EC markers, displaying features of stem/progenitor cells and having high clonogenicity and proliferation rate [10].

ECFCs can be isolated from umbilical cord blood (CBECFCs) [11]. We have demonstrated that these ECFCs give rise to higher number of colonies and can be extensively expanded in-vitro compared to ECFCs derived from adult peripheral blood (APB-ECFCs) and their initial clonogenic potential is predictive of their further properties [12]. Furthermore, unlike adult vascular ECs, ECFCs have not yet acquired specialized functions. In presence of appropriate external stimuli, CB-ECFCs acquire properties of specialized ECs such as brain microvascular or arterial ECs [13]. Therefore, ECFCs still bear stem cell features and this could potentially influence their immunogenic properties.

Inflammatory signaling pathways are crucial for the migration of ECs and initiating angiogenesis [14]. It is known that tumor necrosis factor alpha (TNF $\alpha$ ) is a proinflammatory mediator that could modulate both proand anti-angiogenic properties [15-17]. This dual effect is directly related to the concentration of TNF $\alpha$ and duration of exposure [18]. TNF $\alpha$ interacts with two distinct transmembrane receptors, TNFR1 and TNFR2. TNFR1 is expressed on almost all cell types and its binding with TNF $\alpha$ leads to cell death and apoptosis. TNFR2 is strictly expressed on limited cells such as immune cells, ECs, neural cells and Mesenchymal Stem Cells (MSCs) and its interaction with TNF $\alpha$ leads to cell survival and proliferation [19-21]. Through binding to its receptors, TNF $\alpha$ induces and enhances the expression of many pro-angiogenic factors like vascular endothelial growth factor (VEGF), basic fibroblast growth factor (bFGF), and interleukin-8 (IL-8) in ECs [22-24]. Indeed, TNF $\alpha /$ TNFR2 axis supports pro-angiogenic and protective mechanisms and inversely TNF $\alpha / T N F R 1$ axis is involved in deleterious mechanisms. For example, unlike TNFR1 that mediates myocardiac ischemic injuries and exert a toxic effect in myocardial infraction models [25, 26], TNF $\alpha / T N F R 2$ signaling pathway is protective in adult infract myocardium [27], heart ischemic injuries [28] and aging $[29,30]$. It has been demonstrated in-vivo that ECFC cell survival, mobilization, differentiation, VEGF expression and ultimately ischemia-induced collateral vessel development depend on TNF $\alpha / T N F R 2$ signaling pathway [30]. Furthermore, unlike TNFR2 KO mice, endothelial cell specific transgenesis of TNFR2 revealed a significant promotion in arteriogenesis and angiogenesis in mice [31].

These findings highlight the important implications of ECFCs in conditions which angiogenesis and neovascularization are involved, like in cardiovascular disorders, transplantation and specially cancer. However, little is known about their immunogenicity and the interaction of immune system with these cells in the context of cancer or while administered in an allogenic setting. We have recently demonstrated in a model of bio-artificial vessel that human CB-ECFCs implanted in a microfluidic chambers were able to suppress allogenic $\mathrm{T}$ cells in a dose dependent manner [32]. In addition, we showed that human ECFCs are not only capable of inducing new functional vessels in xenogeneic ischemic immunocompetent mice but are tolerated by host immune system and resistant in several tissues after their first administration [33]. Therefore, we aimed to study the interaction between human ECFCs and mice $\mathrm{T}$ cells in order to understand through what mechanisms human ECFCs are tolerated in highly inflammatory xenogeneic mice model and are able to properly exert their immunological and angiogenic properties.

To investigate the difference between the sources of ECFCs (cord or adult blood) and the mechanism they use to exert their immunosuppressive effect, we considered the following facts: 1) ECFCs are among the rare cells expressing TNFR2 and TNF $\alpha$ is extremely important for their activation, migration and angiogenic activities [14, 30]. 2) We and others have shown that many immunosuppressive cells including regulatory $\mathrm{T}$ cells ( $\mathrm{T}$ regs), regulatory $\mathrm{B}$ cells (B regs) and myeloid derived suppressive cells (MDSCs) express TNFR2 and this is directly related to their immunosuppressive function [34-36]. Therefore, we aimed to investigate 1) the exact effect of ECFCs on T cells, since they are the first line responsible of immunological rejection and 2) if the TNF $\alpha /$ TNFR2 signaling pathways is important for ECFC immunosuppressive function.

We have compared the effect of CB-ECFCs and APBECFCs to differentiated adult human aortic endothelial cells (HAEC) on T cells. We evaluated the proliferation capacity, activation profile and cytokine secretion of both CD4 and CD8 T cells after co-culturing with those ECs. Finally, we interfered in the TNF $\alpha / T N F R 2$ axis and demonstrated for the first time that this signaling pathway is critical in ECFC immunomodulatory effect. 


\section{Methods}

\section{ECFC and HAEC isolation and culture}

Human samples were used in compliance with the declaration of Helsinki. CB samples from healthy full term newborns were obtained from the CB Bank of St Louis Hospital (Paris, France) which is authorized by the French Regulatory Authority (no. PPC51). Human APB from healthy male adults was obtained from the French Establishment of Blood (EFS, authorization 14/5/011). Legal age to give blood ranges from 18 to 70 years. This activity was declared to and authorized by the French Ministry of Research under number AC- 2008-376, and to the French Organization for standardization under number 201/51848.1. Mononuclear cells (MNC), obtained by density gradient centrifugation, were seeded onto rat-tail collagen type-I (BD-Bioscience) coated wells as previously described [13]. ECFC colonies appeared after 7-20 days of culture. From passage 1 (P1), cells were seeded at 5000 cells/cm2 and grew in EGM-2MV medium $+E^{E G M}{ }^{\mathrm{TM}}-2$ Endothelial SingleQuots ${ }^{\mathrm{TM}}$ Kit (Lonza), referred to hereafter as EGM2 medium.

HAECs were purchased from Lonza and seeded at 5000 cells/cm2 and grew in EGM2 medium for further passages.

\section{T cell isolation and culture}

Pan T cell isolation kit II (Miltenyi) was used to isolate total $\mathrm{CD}^{+} \mathrm{T}$ cells from the spleens of 6 to 12 week old female C57BL/6 mice WT (Envigo and Charles River Laboratories) or TNF $\alpha \mathrm{KO}$ mice (B6.129S-Tnf ${ }^{\mathrm{tm} 1 \mathrm{Gkl}} / \mathrm{J}$, The Jackson Laboratory). Furthermore, $\mathrm{CD} 25^{+}$cells were depleted from the $\mathrm{CD}^{+} \mathrm{T}$ cell population using anti-CD25 biotin conjugated antibody (7D4, BD-Biosciences), followed by anti-biotin microbeads staining (Miltenyi). Then, the magnetic-activated cell sorting (MACS) method was used in all cell isolations. The resulting $\mathrm{CD}^{+} \mathrm{CD} 25^{-}$ $\mathrm{T}$ cells, more than $92 \%$ purity, were cultured in the presence of ECs (ECFCs or HAECs). The isolation of T cells from co-culture in presence of ECs is based on the biological capacity of ECs to adhere to plastic plates, however, $\mathrm{T}$ cells stay in suspension, hence, we collected them with gentle aspiration.

\section{In-vitro study design}

\section{We designed the following experimental conditions:}

1- CB-ECFCs + T cells condition: freshly isolated $\mathrm{CD}^{+}{ }^{+} \mathrm{CD} 25^{-} \mathrm{T}$ cells were added to more than $80 \%$ confluent human CB-ECFCs (P3 to P6).

2- APB-ECFCs + T cells condition: freshly isolated $\mathrm{CD}^{+}{ }^{+} \mathrm{CD} 25^{-} \mathrm{T}$ cells were added to more than $80 \%$ confluent human APB-ECFCs (P3 to P5).
3- HAECs + T cells condition: freshly isolated $\mathrm{CD}^{+}{ }^{+} \mathrm{CD} 25^{-} \mathrm{T}$ cells were added to more than $80 \%$ confluent HAECs (P3 to P6).

4- Control condition: freshly isolated $\mathrm{CD}^{+} \mathrm{CD}^{-} 5^{-} \mathrm{T}$ cells were cultured alone.

\section{Co-culture of $T$ cells and ECs}

ECs (APB-ECFCs, CB-ECFCs and HAECs) were seeded in 6 or 12 well plates and incubated for $3 \mathrm{~h}$ in EGM2 medium. Then, mouse $\mathrm{CD}^{+} \mathrm{CD} 25^{-} \mathrm{T}$ cells were added to the ECs at different doses depending on experimental conditions in RPMI medium containing 10\% FBS, 1\% HEPES buffer, and $1 \%$ penicillin/streptomycin/neomycin, referred to hereafter as RPMI medium. All co-culture experiments were performed in 50\% EGM2 and 50\% RPMI. (Hydrocortisone was removed from singlequote of EGM2 medium due to its immunosuppressive effect). In order to stimulate or block the TNFR2 signaling pathway, we used $1 \mathrm{ng} / \mathrm{ml}$ of recombinant-human-TNF $\alpha$ (R\&D system) or $2 \mu \mathrm{g} / \mathrm{mL}$ human-TNFR2/CD120b/TNFRSF1B neutralizing antibody (Sino Biological). This Antibody does not have crossreactivity with mouse TNFR2. T cells were collected after 1 or 3 days of co-culture depending on the experimental condition.

\section{Proliferation assay}

This test was conducted in 12-well plates (Falcon). $5 \times 10^{4}$ ECs (APB- ECFCs, CB- ECFCs or HAECs) were cocultured with 6 increasing doses of mouse $\mathrm{CD} 3^{+} \mathrm{CD} 25^{-}$ responder $\mathrm{T}$ cells in a total volume of $2 \mathrm{ml}$. The doses were $1 / 1,1 / 2,1 / 4,1 / 8,1 / 16,1 / 32$ (ECs/T cells). $10^{5}$ $\mathrm{CD}^{+} \mathrm{CD} 25^{-} \mathrm{T}$ cells were used as control T cells alone. $\mathrm{T}$ cells were stained with Carboxyfluorescein succinimidyl ester (CFSE) (ThermoFisher) and stimulated by Dynabeads mouse $\mathrm{T}$-activator CD3/CD28 (Gibco) according to provided protocol. After 3 days, T cells were collected and immunostained and the percentage of $\mathrm{CFSE}^{+}$cells was measured among $\mathrm{CD}^{+}$and $\mathrm{CD}^{+} \mathrm{T}$ cells.

\section{T cell activation and cytokine measurement}

$5 \times 10^{4}$ ECs (APB- ECFCs, CB- ECFCs or HAECs) were co-cultured with $3 \times 10^{5}$ (1/6 ratio) of mouse $\mathrm{CD}^{+}{ }^{+} \mathrm{CD} 25^{-} \mathrm{T}$ cells in a total volume of $2 \mathrm{ml}$. $\mathrm{CD}^{+} \mathrm{CD} 25^{-} \mathrm{T}$ cells were then stimulated by Dynabeads mouse T-activator CD3/CD28 (Gibco) in compliance with provided protocol. According to proliferation assay, $1 / 6$ is the ratio which CB-ECFCs suppress $50 \%$ of responder $\mathrm{T}$ cell proliferation. After either 1 or 3 days, $\mathrm{CD}^{+} \mathrm{CD} 25^{-} \mathrm{T}$ cells were collected and proceeded with immunostaining. $3 \times 10^{5}$ freshly isolated $\mathrm{CD}^{+} \mathrm{CD}^{2} 5^{-} \mathrm{T}$ cells were used as control $\mathrm{T}$ cells alone. For intracellular cytokine staining, cells were stimulated with $1 \mu \mathrm{g} / \mathrm{mL}$ PMA and $0.5 \mu \mathrm{g} / \mathrm{mL}$ Ionomicyn (Sigma) for $4 \mathrm{~h}+1 \mathrm{~h}$ with $1 \mu \mathrm{L} / \mathrm{mL}$ GolgiPlug (BD-Biosciences). 


\section{Flow cytometry}

Cells were immunostained with the following mAbs: CD31-FITC, CD144-vioblue, KDR-PE-Vio770, CD4FITC, APC and Vioblue, Foxp3-APC, CD62L-PE, ICOS-PE, CTLA4-biotin or PE, IFN $\gamma-\mathrm{APC}$, TNF $\alpha-$ FITC or PE, IL-10-APC, IL-17-PE, IL-2-FITC, HLA-GPE, TGF $\beta$-biotin, REA-control-APC, PE, PE-Cy5 and PE-Cy7, CD8 $\alpha$-FITC or Percp or PE-Cy7 and TNFR2$\mathrm{APC}$ and PE (Miltenyi) streptavidin-PE-Cy7 or PE-Cy5, Foxp3-PE-Cy5, CD25-PE-Cy7 (eBioscience) and TGF $\beta$ PE (Biolegend). Intracellular Foxp3 staining was performed according to the manufacturer's instructions, using Foxp3 staining buffer set from eBioscience. Events acquired on a LSRFORTESSA flow cytometer (BD-Biosciences) and analyzed using FlowJo software v10 (FlowJo-LLC).

\section{Statistical analysis}

Prism (GraphPad) was used for statistical analysis. Shapiro-Wilk normality test was performed to assess the normal distribution of data. Student $t$ test or 1-way ANOVA with post hoc analysis was performed depending on the number of comparatives. For cytometry analysis, we have normalized the MFI values with T-cell alone control group. Then we used unpaired, 2-tailed Student $t$ tests or 1-way ANOVA for $P$ value generation.

\section{Results}

\section{ECFCs suppress $T$ cell proliferation}

We first investigated the immunogenic effect of undifferentiated ECFCs on $\mathrm{T}$ cells compared to differentiated HAECs. CB-ECFCs, ABP-ECFCs and HAECs were cocultured with CFSE labeled mouse $\mathrm{CD}^{+} \mathrm{CD} 25^{-}$responder $\mathrm{T}$ cells in 6 different ratios (1/1 to $1 / 32$ for $\mathrm{ECs} / \mathrm{T}$ cells). CD25 ${ }^{+} \mathrm{T}$ cells were depleted from starting $\mathrm{T}$ cell population to eliminate 1 ) activated $\mathrm{T}$ cells and 2) unspecific immunosuppression by $\mathrm{T}$ regs. After 3 days of co-culture, total $\mathrm{T}$ cells were collected (cells in suspension). The proliferation capacity of two main subpopulations of $\mathrm{T}$ cells $\left(\mathrm{CD} 4^{+}\right.$and $\mathrm{CD} 8^{+} \mathrm{T}$ cells) was then studied. Since, two different media are used for $\mathrm{T}$ cells (RPMI medium) and ECs (EGM2 medium); we used $50 \%$ of each medium in co-culture. To observe the effect of EGM2 medium on T cells, two control group were added in which $\mathrm{T}$ cells alone were cultured either in $100 \%$ RPMI medium or in $50 \%$ EGM $2+50 \%$ RPMI media. No difference was observed between those controls throughout the entire experiments (Fig. 1). Likewise, the co-culture of HAECs with $\mathrm{T}$ cells did not change the proliferation capacity of neither $\mathrm{CD} 4^{+}$nor $\mathrm{CD}^{+}$responder $\mathrm{T}$ cells regardless of different ratio conditions (Fig. 1a, Sup Figure 1). However, we observed a significant decrease in proliferation capacity of both $\mathrm{CD}^{+}$and $\mathrm{CD}^{+} \mathrm{T}$ cells while co-cultured with $\mathrm{APB}-$
ECFCs (Fig. 1b, Sup Figure 1). The significant immunosuppressive effect was only observed in $1 / 1$ and $1 / 2$ ratios (34.12 and $11.2 \%$ of suppression, respectively) for $\mathrm{CD} 4^{+} \mathrm{T}$ cells and equally for $\mathrm{CD} 8^{+} \mathrm{T}$ cells (52.65 and $22.55 \%$ of suppression, respectively) and then was lost for more elevated doses of $\mathrm{T}$ cells (Fig. 1b). An even stronger dose dependent immunosuppression of $\mathrm{T}$ cells was found while co-cultured with CB-ECFCs, starting from $1 / 1$ (53.6\% of suppression) up to $1 / 16$ (9.69\% of suppression) ratio for $\mathrm{CD}^{+} \mathrm{T}$ cells and from $1 / 1$ (41.84\% of suppression) up to $1 / 8$ ratios (15\% of suppression) for $\mathrm{CD}^{+} \mathrm{T}$ cells (Fig. 1c, Sup Figure 1). Hence, we report a remarkable dose dependent immunosuppressive effect of ECFCs on $\mathrm{T}$ cells which is not observed in other differentiated ECs such as HAECs. Moreover, we demonstrate that this immunosuppressive effect was more accentuated in CB-ECFCs compared to APB-ECFCs.

\section{ECFCs modulate $\mathrm{CD} 4^{+} \mathrm{T}$ cell activation markers}

We then investigated if ECFCs are able to modulate the activation profile of both $\mathrm{CD} 4^{+}$and $\mathrm{CD} 8^{+} \mathrm{T}$ cells. Therefore, HAECs, CB-ECFCs and APB-ECFCs were cocultured with mouse $\mathrm{CD}^{+} \mathrm{CD} 25^{-} \mathrm{T}$ cells for periods of 1 and 3 days since the first few days after transplantation is crucial in case of inflammatory responses [37]. Total $\mathrm{T}$ cells were harvested and further analyzed for the percentage of expression and mean fluorescence intensity (MFI) of different activation markers among conventional $\mathrm{CD}^{+}{ }^{+}$Foxp3 $^{-} \mathrm{T}$ cells $\left(\mathrm{CD} 4^{+} \mathrm{T}\right.$ convs). We first measured the expression of CD25; $\alpha$ chain of the IL-2 receptor, constitutively expressed on $\mathrm{T}$ regs and activated $\mathrm{T}$ cells $[38,39]$. After 3 days, we observed a dramatic decrease of the percentage of $\mathrm{CD} 25^{+}$cells and $\mathrm{CD} 25$ expression level among $\mathrm{CD} 4^{+} \mathrm{T}$ convs, only when co-cultured with CB-ECFCs or APB-ECFCs and not with HAECs (Fig. 2). Moreover, we evaluated the expression of two members of TNF $\alpha$ receptor superfamily, GITR (TNFRSF18) and TNFR2 (CD120b or TNFRSF1B). Three days after co-culture, we observed a remarkable decrease in expression level of GITR and percentage of expression of TNFR2 marker among $\mathrm{CD} 4^{+} \mathrm{T}$ convs, only when co-cultured with CB-ECFCs or APB-ECFCs and not with HAECs (Fig. 2). Finally, we studied the expression of inducible co-stimulatory molecule (ICOS) among $\mathrm{CD}^{+}{ }^{+} \mathrm{T}$ convs. It was shown that ICOS co-stimulatory receptor is essential for $\mathrm{T}$ cell activation and proliferation [40]. After 3 days of co-culture, we observed a significant reduction in percentage of $\operatorname{ICOS}^{+}$cells among $\mathrm{CD} 4^{+} \mathrm{T}$ convs only in co-culture condition with APBECFCs and a decrease in expression level after coculture with both CB-ECFCs and APB-ECFCs and never with HAECs (Fig. 2). All the mentioned activation markers were also measured on $\mathrm{CD}^{+} \mathrm{T}$ convs, 1 day 


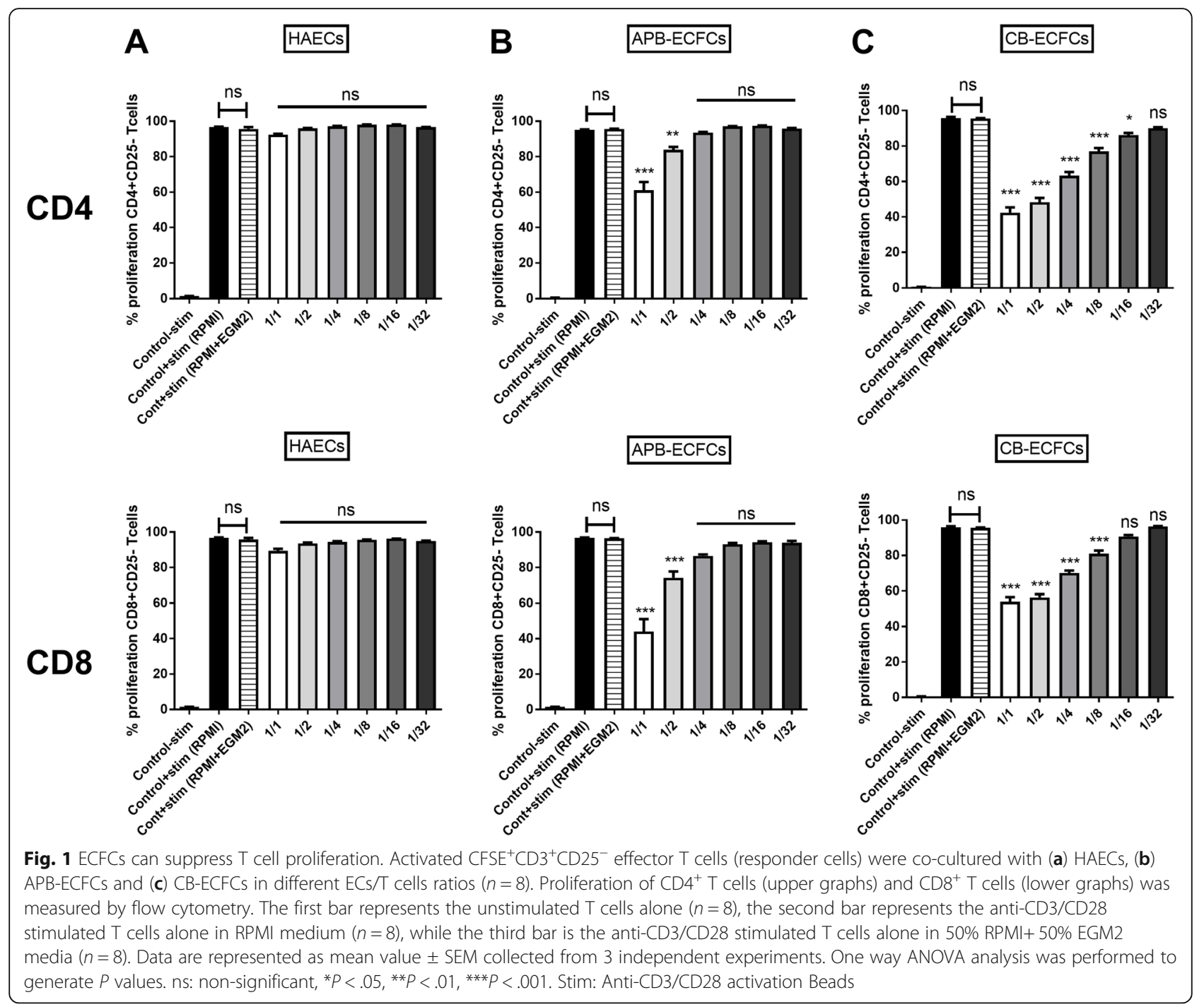

after co-culture with different ECs. We did not observe a significant alter in the percentage of expression of none of those markers; however, the MFI of all $\mathrm{T}$ cell activation markers was dramatically decreased only when cocultured with ECFCs (Sup Figure 2). No significant difference was noticed between CB-ECFCs and APBECFCs in regard to downregulation of measured markers. Altogether, these data suggest that unlike differentiated ECs, ECFCs from both CB and APB sources are able to strongly down-modulate $\mathrm{CD}^{+} \mathrm{T}$ cells activation which is in accordance with their less proliferative capacity (Fig. 1).

\section{ECFCs modulate $\mathrm{CD} 8^{+} \mathrm{T}$ cell activation markers}

To investigate the effect of different ECs on cytotoxic $\mathrm{T}$ cells, HAECs, CB-ECFCs and APB-ECFCs were cocultured with $\mathrm{CD} 3^{+} \mathrm{CD} 25^{-}$responder $\mathrm{T}$ cells for periods of 1 and 3 days. $T$ cells were collected and further analyzed for the percentage of expression and MFI of different activation markers among conventional $\mathrm{CD}^{+}$Foxp $^{-} \mathrm{T}$ cells $\left(\mathrm{CD} 8^{+} \mathrm{T}\right.$ convs). After 3 days, we observed a dramatic decrease of the percentage of $\mathrm{CD}_{25} 5^{+}$cells and CD25 expression level among $\mathrm{CD}^{+} \mathrm{T}$ convs, only when co-cultured with $\mathrm{CB}-$ ECFCs or APB-ECFCs and not with HAECs (Fig. 3). This effect was more accentuated in $\mathrm{T}$ cells collected from the co-culture of CB-ECFCs as compared to APB-ECFCs. Furthermore, our data revealed a significant decrease in the expression level of GITR only in $\mathrm{T}$ cells $+\mathrm{CB}$-ECFCs group and the percentage of expression of TNFR2 among $\mathrm{CD} 8^{+} \mathrm{T}$ convs, only when co-cultured with CB-ECFCs or APB-ECFCs and not with HAECs (Fig. 3). Finally, we noticed a significant reduction in percentage of $\mathrm{ICOS}^{+}$cells and its expression level on $\mathrm{CD}^{+} \mathrm{T}$ convs only in co-culture condition with CB-ECFCs and APB-ECFCs and never with 

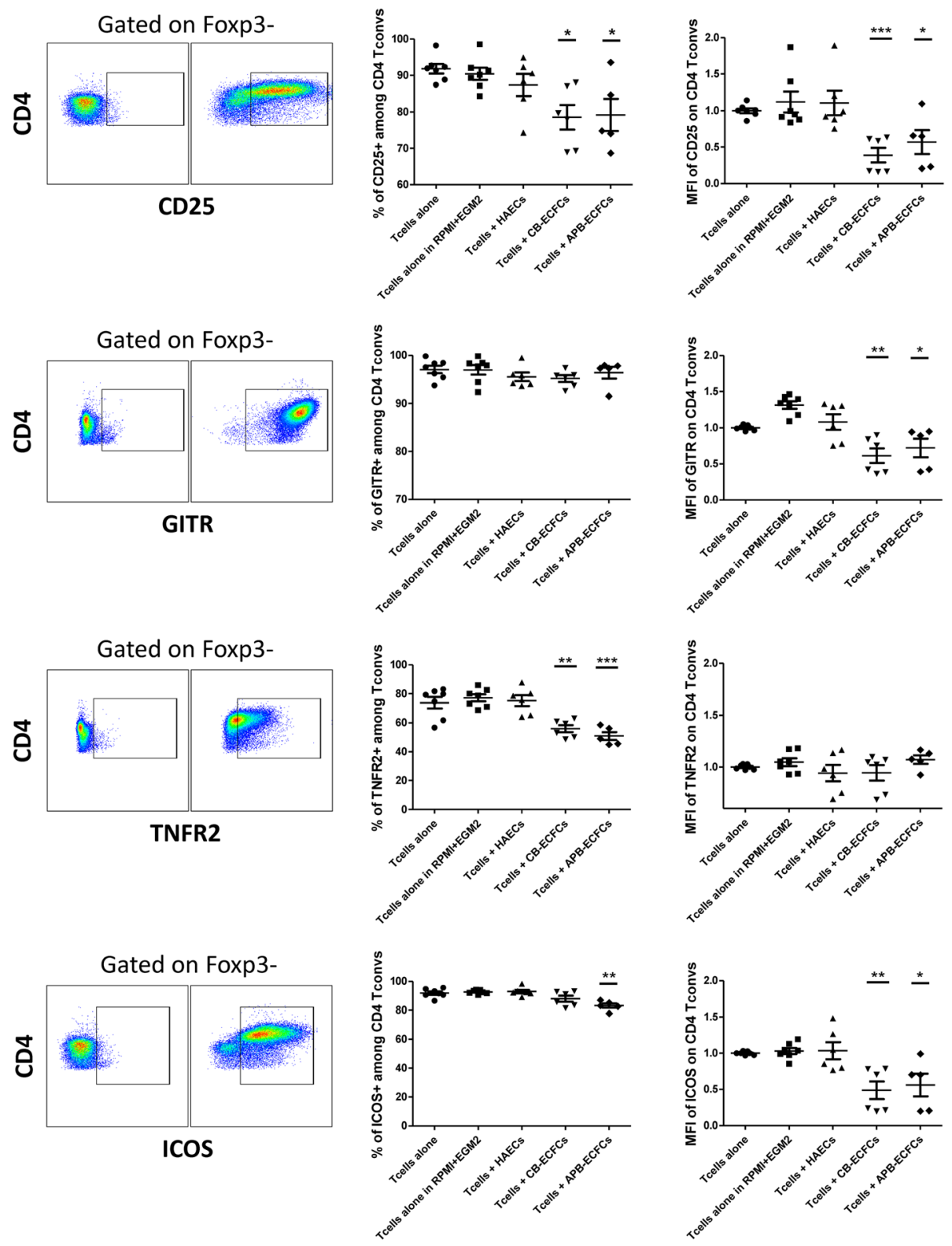

Fig. 2 ECFCs can modulate CD4 ${ }^{+} T$ cell activation markers. Anti-CD3/CD28 activated CD $3^{+} C D 25^{-}$effector $T$ cells were co-cultured with HAECs, CB-ECFCs and APB-ECFCs in fixed 1/6 ratio. After 3 days, T cells were collected and different activation markers were studied. Cells were gated on $\mathrm{CD}^{+} \mathrm{Foxp}^{-}$conventional T cells. For each marker the strategy of gating is indicated on the left and below the figure. The representative gating panels on the left demonstrate fluorescence minus one (FMO) controls. Each dot represents a measured value $(n=7$ for Tcells alone, Tcells alone in RPMI+EGM2 media and $n=6$ for Tcells + HAECs, Tcells + CB-ECFCs and $n=5$ for Tcells + APB-ECFCs) collected from 2 independent

experiments. For each group of values, horizontal lines represent mean value and standard error of the mean. MFI values have been normalized with T cells alone control group. One way ANOVA analysis was performed to generate $P$ values. ns: non-significant, ${ }^{*} P<.05$, ${ }^{* *} P<.01,{ }^{* * *} P<.001$

HAECs (Fig. 3). All the mentioned activation markers were also measured on $\mathrm{CD}^{+} \mathrm{T}$ convs, 1 day after coculture in presence of different ECs. We did not observe a significant alter in the percentage of expression of CD25 and GITR markers, however, their expression level was remarkably decreased (Sup Figure $3)$. Moreover, both the percentages of expression and MFI of TNFR2 and ICOS significantly decreased in T
cells+CB-ECFCs and $\mathrm{T}$ cells+APB-ECFCs group and not in $\mathrm{T}$ cells+HAECs group. No significant difference was noticed between CB-ECFCs and APB-ECFCs in regard to downregulation of mentioned activation markers. These data suggest that only CB- and APBECFCs are capable of down-modulating $\mathrm{CD}^{+} \mathrm{T}$ cells activation which is in accordance with their less proliferative capacity (Fig. 1). 

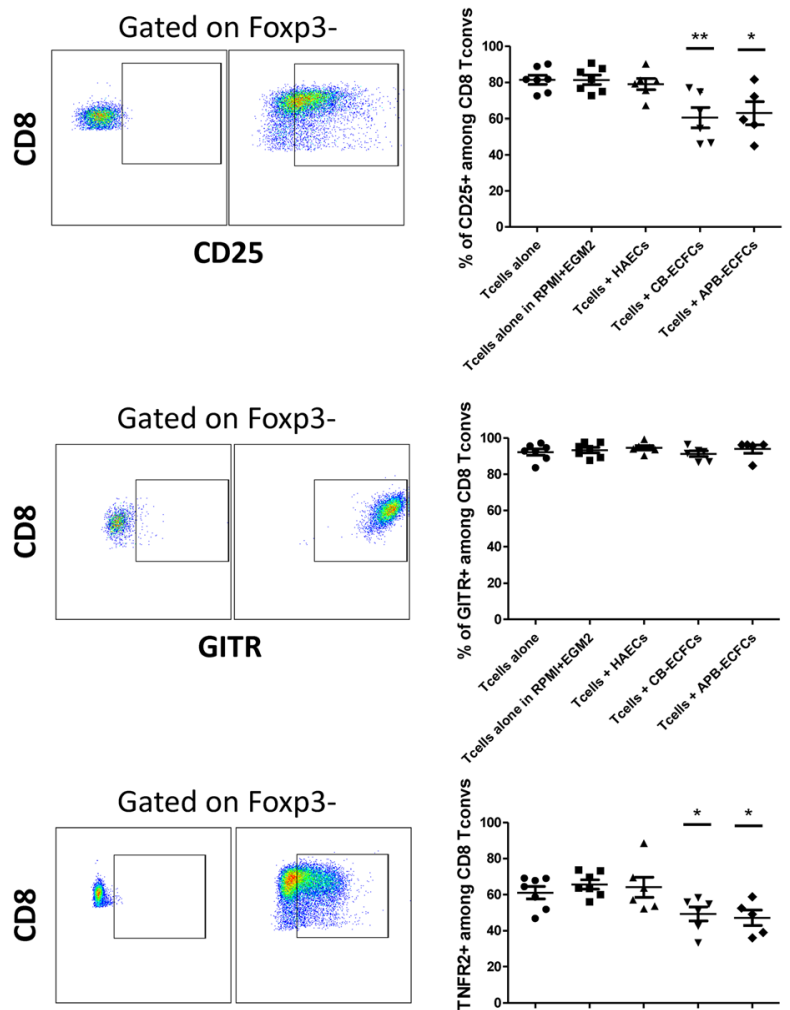

TNFR2
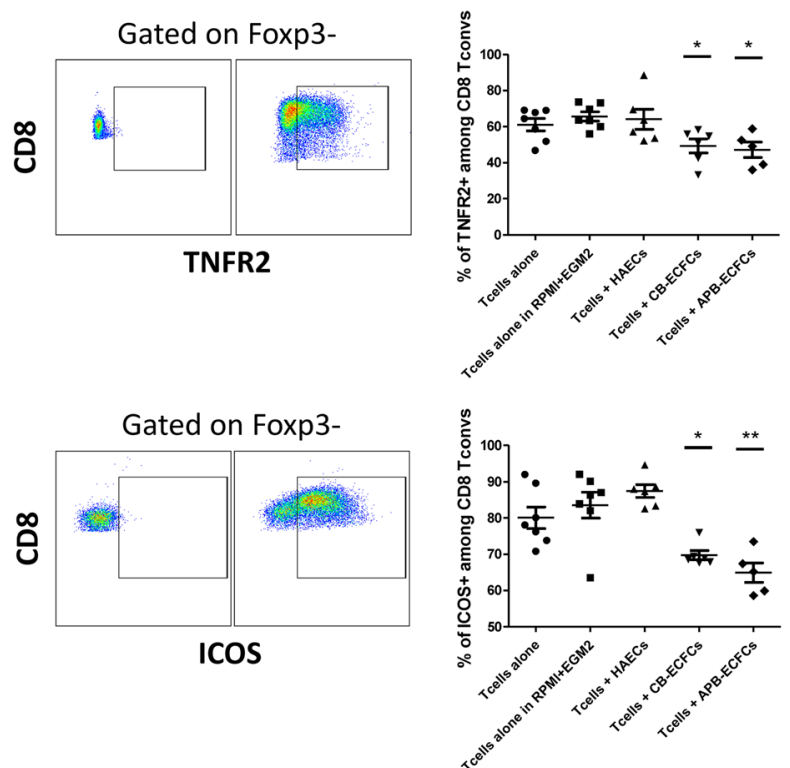
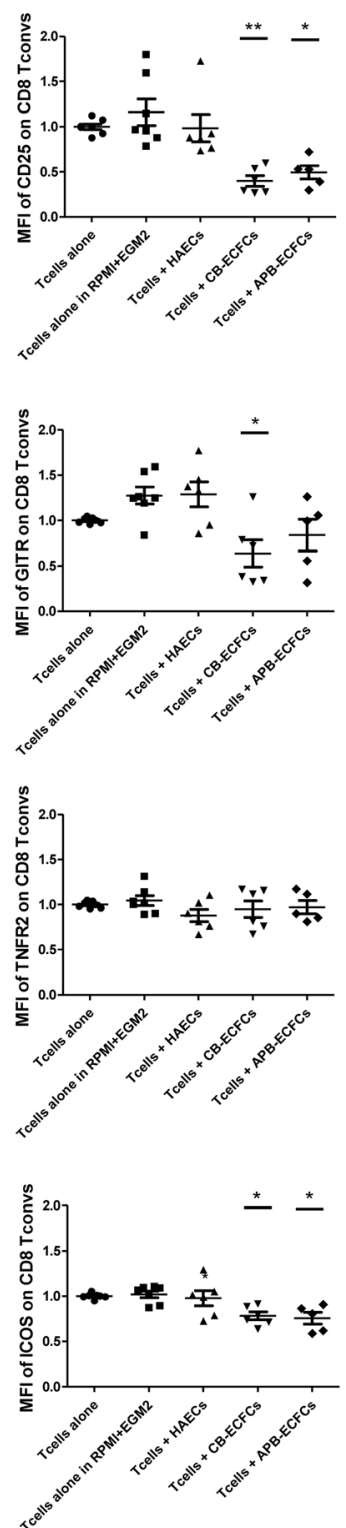

Fig. 3 ECFCs can modulate CD8 ${ }^{+} T$ cell activation markers. Anti-CD3/CD28 activated CD3 ${ }^{+} C D 25^{-}$effector $T$ cells were co-cultured with HAECs, CB-ECFCs and APB-ECFCs in a fixed 1/6 ratio. After 3 days, T cells were collected and different activation markers were studied. Cells were gated on $\mathrm{CD}^{+}{ }^{+} \mathrm{Foxp}^{-}$conventional T cells. For each marker the strategy of gating is indicated on the left and below the figure. The representative gating panels on the left demonstrate FMO controls. Each dot represents a measured value ( $n=7$ for Tcells alone, Tcells alone in RPMI+EGM2 and $n=6$ for Tcells + HAECs, Tcells + CB-ECFCs and $n=5$ for Tcells + APB-ECFCs) collected from 2 independent experiments. For each group of values, horizontal lines represent mean value and standard error of the mean. MFI values have been normalized with $T$ cells alone control group. One way ANOVA analysis was performed to generate $P$ values. ns: non-significant, ${ }^{*} P<.05,{ }^{* *} P<.01,{ }^{* * *} P<.001$

\section{ECFCs reduce the capacity of T cell pro-inflammatory cytokine production}

After activation, $\mathrm{T}$ cells produce anti- or pro-inflammatory cytokines. We examined the effect of ECFCs on T cell cytokine production capacity. We quantified the principle cytokines secreted by four main sub-populations of $\mathrm{T}$ helpers (Th1, Th2, Th17 and T reg) and cytotoxic $\mathrm{T}$ cells (Tc1, Tc2, Tc17 and T reg). CB-ECFCs, APB-ECFCs and HAECs were co-cultured with mouse $\mathrm{CD}^{+} \mathrm{CD}^{+} 5^{-} \mathrm{T}$ cells. 3 days after, $\mathrm{T}$ cells were collected and analyzed for their cytokine production capacity. We first assessed the ability of $\mathrm{T}$ cells to produce anti-inflammatory cytokines. No IL-10 and TGF $\beta$ production was observed neither by $\mathrm{CD} 4^{+}$nor $\mathrm{CD} 8^{+}$ $\mathrm{T}$ cells (data not shown). Furthermore, we investigated the capacity of $\mathrm{T}$ cells to produce pro-inflammatory cytokines. Interestingly, we observed an impressive reduction in production of TNF $\alpha$, IFN $\gamma$, IL- 2 and IL-17 both by $\mathrm{CD}^{+}$and $\mathrm{CD}^{+} \mathrm{T}$ convs, merely, after co-culturing with ECFCs and 
not with HAECs (Fig. 4). Our results did not reveal any difference in cytokine production between $\mathrm{T}$ cells alone and $\mathrm{T}$ cells+HAECs group. However, the comparison between CB-ECFCs and APB-ECFCs revealed a trend for stronger immunomodulatory effect by CB-ECFCs (Fig. 4).

\section{ECFC immunosuppressive effect is TNFa/TNFR2 dependent}

To understand by which mechanism ECFCs exert their immunosuppressive effect, we investigated if the TNF $\alpha$ /
TNFR2 axis is involved in the observed results. We reproduced $\mathrm{T}$ cell proliferation assay in co-culture with different ECs while blocking the TNF $\alpha / T N F R 2$ signaling pathway via treatment by anti-TNFR2 neutralizing antibody (anti-TNFR $2 \mathrm{mAb}$ ). In this setting, TNF $\alpha$ produced by activated $\mathrm{T}$ cells (membrane and secreted forms) will not interact with TNFR2 expressed by ECFCs (Fig. 5a). We noticed that blocking TNFR2 had no impact neither on $\mathrm{CD}^{+}$nor $\mathrm{CD}^{+} \mathrm{T}$ cell proliferation when cocultured with HAECs (Fig. 5b). However, interestingly,
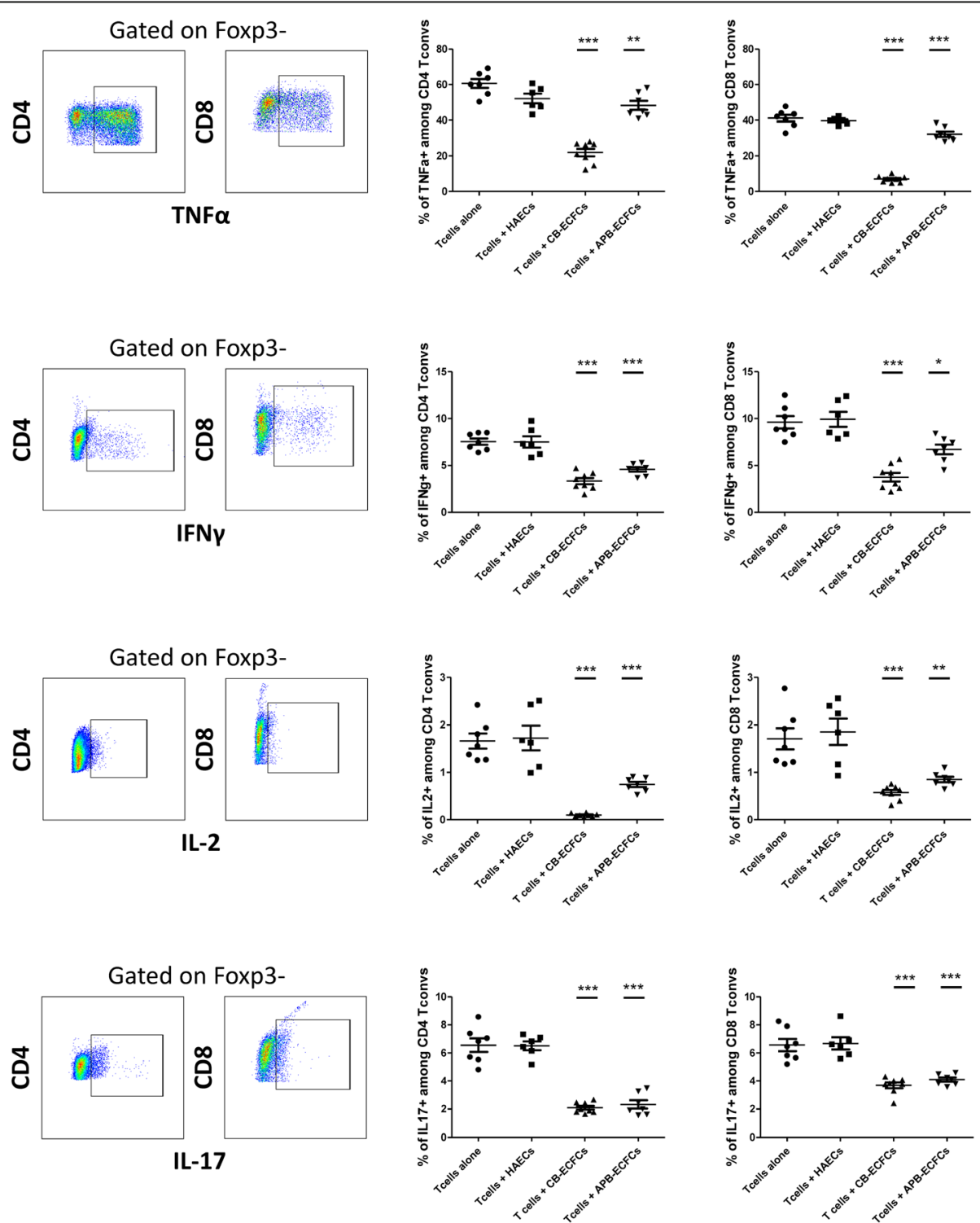

Fig. 4 ECFCs can reduce the capacity of T cells to produce pro-inflammatory cytokines. CD ${ }^{+} C D 25^{-} \mathrm{T}$ cells were co-cultured with $\mathrm{HAECS}$, CBECFCs and APB-ECFCs in a fixed 1/6 ratio. After 3 days, T cells were collected, activated with PMA/lonomycin and then treated with Golgi Plug (a protein transport inhibitor). Intracellular cytokine production was determined in both $\mathrm{CD}^{+}$(left graphs) and CD8 ${ }^{+} \mathrm{T}$ cells (right graphs) by flow cytometry. Cells were gated on $\mathrm{CD}^{+} \mathrm{Foxp}^{-}$or $\mathrm{CD}^{+} \mathrm{Foxp}^{-} \mathrm{T}$ cells. For each marker the gating strategy is indicated on the left and below the figure. Each dot represents a measured value ( $n=7$ for Tcell alone, $n=6$ for HAEC group, $n=8$ for Tcells + CB-ECFCs group and $n=7$ for Tcells + APB-ECFCs group) collected from 2 independent experiments. For each group of values, horizontal lines represent mean value and standard error of the mean. One way ANOVA analysis was performed to generate $P$ values. ns: non-significant ${ }^{*} P<.05,{ }^{* *} P<.01,{ }^{* * *} P<.001$ 
the immunosuppressive effect of CB-ECFCs and APBECFCs was fully abolished while treated with antiTNFR2 $\mathrm{mAb}$ in all the ratios of both $\mathrm{CD} 4^{+}$and $\mathrm{CD} 8^{+} \mathrm{T}$ cells (Fig. $5 \mathrm{c}$ and d).

To reinforce our results, we used a second in-vitro model to block TNF $\alpha / T N F R 2$ signaling pathway by using TNF $\alpha$-deficient $\mathrm{T}$ cells harvested from TNF $\alpha \mathrm{KO}$ mice. These $\mathrm{T}$ cells do not produce any $\mathrm{TNF} \alpha$ but ECFCs express TNFR2 (Sup Figure 4a). Again, in the absence of TNF $\alpha$, neither HAECs nor ECFCs were capable to suppress different $\mathrm{T}$ cell populations proving the importance of this signaling pathway (Sup Figure $4 \mathrm{~b}, \mathrm{c}, \mathrm{d}$ and e).

\section{TNFa/TNFR2 signaling pathway regulates ECFC anti- inflammatory cytokine production}

We have shown that ECFCs are able to produce TGF $\beta$, IL-10 and HLA-G cytokines. TNF $\alpha /$ TNFR2 signaling pathways is an immune-checkpoint that changes the balance of immune response in both directions $[19,35]$. It was reported that there is a direct relation between the expression of TNFR2 and increased secretion of IL-10 and TGF $\beta[36,41]$. Therefore, we investigated if stimulation or blocking TNFR2 signaling pathway could change anti-inflammatory cytokine production by ECFCs. We focused on $\mathrm{CD} 1^{+} \mathrm{CD} 144^{+} \mathrm{KDR}^{+}\left(\mathrm{VEGFR} 2^{+}\right.$) CB-ECFCs (Fig. 6a) and confirmed that they indeed produce the anti-inflammatory cytokines TGF $\beta$, IL-10 and HLA-G at basal level (Fig. 6b). Furthermore, we stimulated TNFR2 by addition of $1 \mathrm{ng} / \mathrm{ml} \mathrm{TNF} \alpha$ or inversely, blocked it using $2 \mu \mathrm{g} / \mathrm{ml}$ anti-TNFR2 $\mathrm{mAb}$ before adding TNF $\alpha$. We observed that the addition of TNF $\alpha$ can significantly boost TGF $\beta$, IL-10 and HLA-G production compared to basal level (Fig. 6c). Conversely, using anti-TNFR2 mAb has significantly decreased TGF $\beta$ and IL-10 production and lowered HLA-G production (Fig. 6c).

\section{Discussion}

Here, we first compared the immunogenicity of CBECFCs and APB-ECFCs to differentiated HAECs using different co-culture conditions with mouse $\mathrm{T}$ cells. Unlike HAECs, both CB-ECFCs and APB-ECFCs were immunosuppressive against $\mathrm{CD} 4^{+} \mathrm{Foxp}^{-}$and $\mathrm{CD} 8^{+} \mathrm{Foxp}^{-}$ $\mathrm{T}$ cells in a dose dependent manner. This finding is important since no specific marker is yet discovered to distinguish between EPCs and other ECs, therefor, could be a functional test to characterize them.

We then investigated the effect of ECFCs on activation profile of $\mathrm{T}$ cells by quantifying different markers like CD25, ICOS, GITR and TNFR2 on mouse T cells after co-culturing them with human ECs. Again, unlike HAECs, CB-ECFCs and APB-ECFCs decreased all activation markers on both $\mathrm{CD} 4^{+}$and $\mathrm{CD}^{+}$populations, beginning from day 1 and stonger at day 3. Among different $\mathrm{T}$ cell activation markers, we targeted two TNF $\alpha$ receptor superfamily members, GITR and TNFR2, expressed by activated $\mathrm{T}$ cells $[42,43]$ and demonstrated a significant decrease in their expression merely by ECFCs and not by HAECs. This reflects a complex modulation of TNF $\alpha$ signaling in $\mathrm{T}$ cells in the presence of ECFCs. Our results extend the idea that when TNFR2 is decreased on $\mathrm{T}$ cells, they will be more efficiently suppressed by immunosuppressive cells like $T$ regs [43] and here by ECFCs. Finally, to investigate the effect of ECFCs on $\mathrm{T}$ cell function, we measured their capacity to produce different cytokines like TGF $\beta$, IL-10, IL-2, IL17, TNF $\alpha$ and IFN $\gamma$. We demonstrated a significant reduction in the percentage of pro-inflammatory cytokine producing $\mathrm{T}$ cells co-cultured with CB-ECFCs and APBECFCs and not by HAECs. Our first hypothesis was that ECFCs might convert $\mathrm{T}$ conv to $\mathrm{T}$ regs that are further producing anti-inflammatory cytokines, the mechanism that is widely accepted for MSCs [44-46]. However, we did not find any IL-10 and TGF $\beta$ production neither by $\mathrm{CD}^{+}$nor by $\mathrm{CD}^{+} \mathrm{T}$ cells. This is in accordance with the absence of Foxp3 induction in $\mathrm{T}$ convs after coculturing with ECFCs or HAECs (data not shown). Thus, ECFC immunosuppressive effect is not $\mathrm{T}$ reg dependent.

These findings suggest that unlike HAECs with destined specialized functions, ECFCs are not yet specialized and there could be a direct relation between stem cell features and the immunoregulatory properties of ECFCs. Accordingly, other studies reported that stem cells derived from neonatal sources are less susceptible to immune rejection compared to adult cells [47].

These results are extremely important in the field of tissue engineering and for creating bio-artificial organs such as bio-artificial vessel and bio-artificial lung which implanted allogenic ECs are in direct contact with patient's blood. ECFCs from both $\mathrm{CB}$ and APB sources are demonstrating immunosuppressive and anti-inflammatory properties against total peripheral blood mononuclear cells [33] and particularly $\mathrm{T}$ cells, as proved here; therefore, they could be the ideal EC choice since they could tolerate allogenic responses and avoid immune rejection.

In the next step, we investigated through which mechanism ECFCs exert their immunoregulatory function. It has been shown that effector $\mathrm{T}$ cell activation can boost $\mathrm{T}$ reg expansion and function, a phenomenon partly dependent on TNF $\alpha[48,49]$. In the context of GVHD, we showed that preventing TNF/TNFR2 interaction abolished $\mathrm{T}$ reg immunosuppressive effect $[35,50]$. In addition, other studies reported that immunosuppressive cells including B reg and MDSCs, also express TNFR2 and this is directly related to their immunosuppressive function [34, 36]. ECs also express TNFR2 and interestingly this expression is higher on ECFCs than on HAECs. 


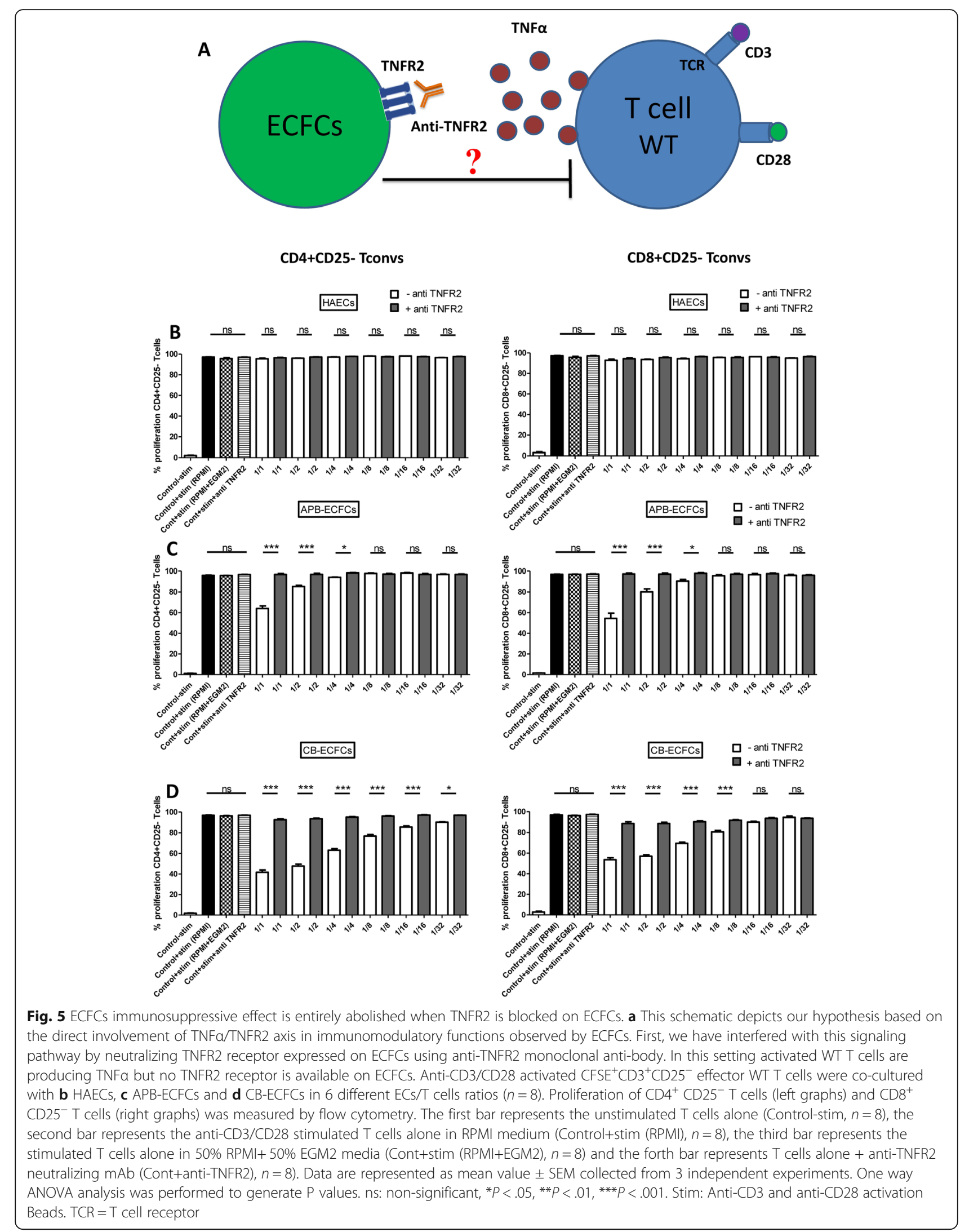




\section{A}
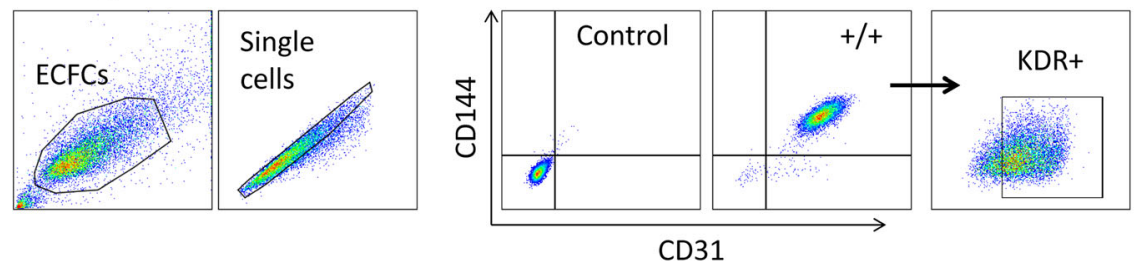

B

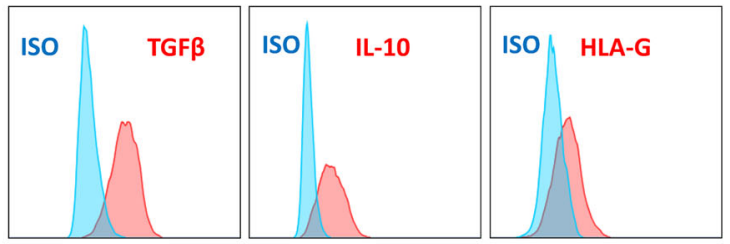

C
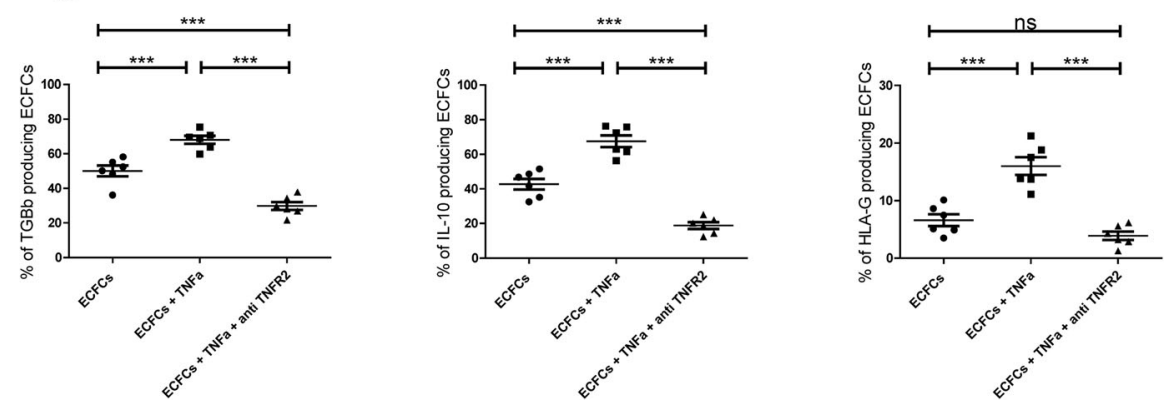

Fig. 6 TNFa/TNFR2 signaling pathway can regulate anti-inflammatory cytokine production by ECFCs. a A representative of the gating strategy for selecting $\mathrm{CD} 31^{+} \mathrm{CD} 144^{+} \mathrm{KDR}{ }^{+}$ECFCs. $\mathbf{b}$ A representative of flow cytometry analysis depicting ECFC's capacity to produce anti-inflammatory cytokines TGF $\beta$, IL-10 and HLA-G. c CB-ECFCs were treated either with TNFa or with anti-TNFR2 neutralizing mAb 1 day prior TNFa addition and their capacity to produce TGF $\beta$, IL-10 and HLA-G production were compared with untreated ECFCs (basal level). Each dot represents a measured value $(n=6)$ collected from 2 independent experiments. For each group of values, horizontal lines represent mean value and standard error of the mean. One way ANOVA analysis was performed to generate $P$ values. ns: non-significant, ${ }^{*} P<.05,{ }^{* *} P<.01,{ }^{* * *} P<.001$. KDR $=$ CD309 or VEGF receptor type 2 , ISO = Isotype control

Inversely, HAECs express higher TNFR1 levels (Sup Figure 5). Moreover, TNF $\alpha$ is crucial for ECFC physiological function $[14,30,51]$. Thus, we investigated the role of TNF $\alpha / T N F R 2$ signaling pathways on ECFC immunosuppressive function. We interfered in the TNF $\alpha$ /TNFR2 axis and demonstrated for the first time that it is critical in ECFC immunomodulatory effect. Our findings rely on two experimental approaches (blocking with anti-TNFR2 $\mathrm{mAb}$ and using TNF $\alpha$-deficient $\mathrm{T}$ cells) and performed on two sources of EPCs (CB-ECFCs and APB-ECFCs).

The expression of TNFR2 on immunosuppressive cells is related to their increased capacity of IL-10 and TGF $\beta$ secretion $[36,41]$. CB-CD34 ${ }^{+}$cells express different isoforms of HLA-G molecules [52]. Accordingly, we observed that ECFCs produce IL-10, TGF $\beta$ and HLA-G anti-inflammatory cytokines even at basal level without any activation. Interestingly, adding TNF $\alpha$ significantly boosted the production of those cytokines. Indeed this effect cannot be TNFR1 dependent since blocking TNFR2 (while only TNFR1 is available) has decreased the production of those cytokines. Inflammatory factors, like IL-1, TNF $\alpha$ and IFN $\gamma$, promote MSC and T reg immunoregulatory functions [53-56]. Accordingly, we report that TNFa enhances the ECFC immunomodulation in an inflamed environment. These data demonstrates that TNFR2 is an immune checkpoint molecule playing as a tuning system for ECFCs, enabling regulation of their immunological features. Once TNFR2 is stimulated by its agonist, it boosts the anti-inflammatory profile of ECFCs and once it is blocked by proper antagonist, it hampers that function.

It will be interesting to investigate the in-vivo effect of anti-TNFR2 therapy on formation of new vessels and immunosuppression by ECFCs.

In cancer, it has been shown that tumor cells through different mechanisms including VEGF and TNF $\alpha$ secretion are able to recruit ECFCs to form new vessels (Fig. 7) [57-60]. It would be interesting to apply antiTNFR2 treatment and measure tumor neo-vascularization and progression in real time after injection of labelled 


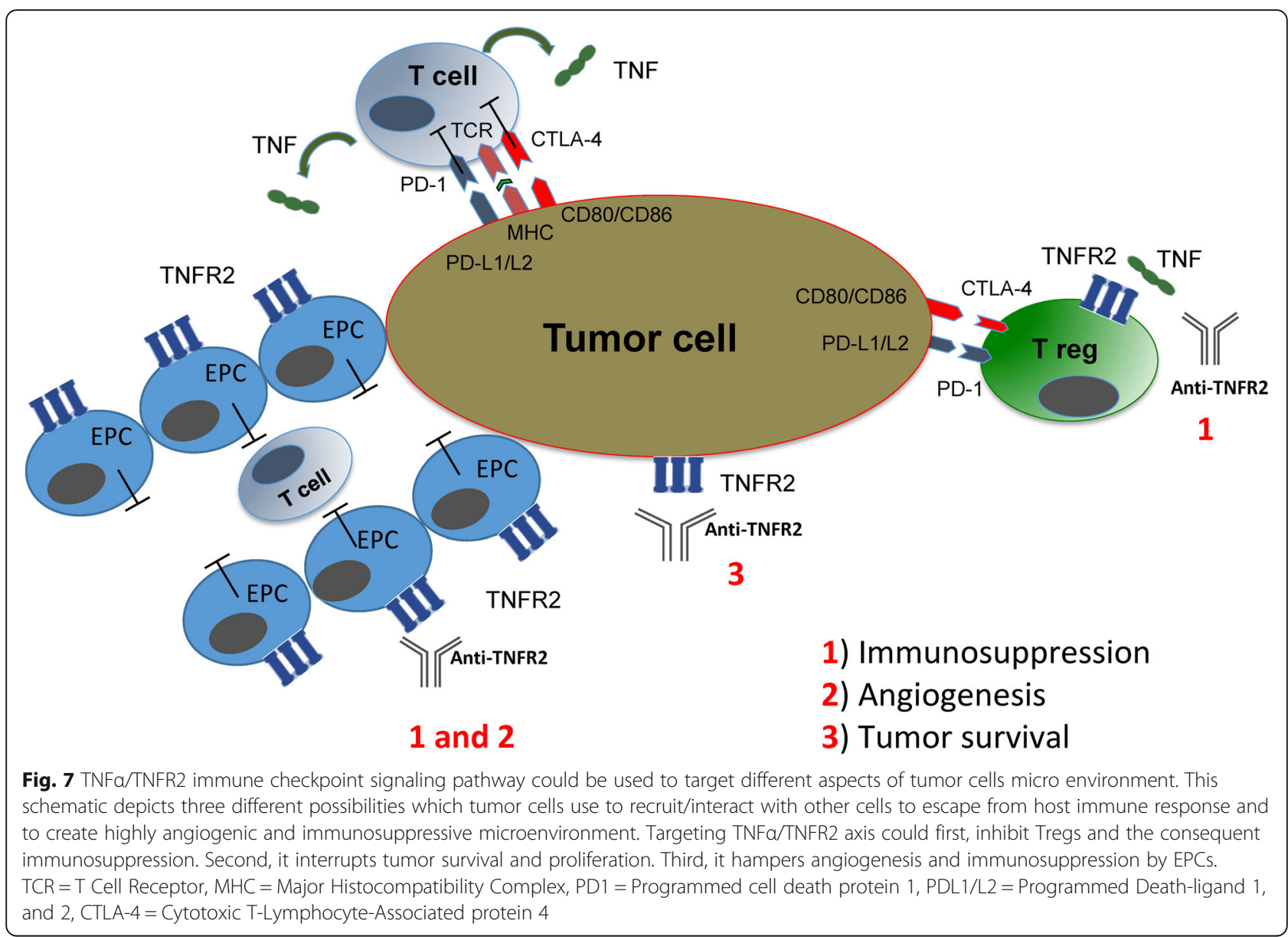

ECFCs. We are convinced that, blocking the TNF/TNFR2 signaling pathway is truly one stone three birds in cancer microenvironment. First, it inhibits $\mathrm{T}$ regs and the consequent immunosuppression. Second, it interrupts tumor survival and proliferation. Recent publications revealed that some tumor cells are also expressing TNFR2 marker and administration of anti-TNFR2 directly eradicated them $[61,62]$. Third, and more interesting, it could hamper tumor angiogenesis and immunosuppression caused by EPCs (Fig. 7).

\section{Conclusions}

Here we report that unlike differentiated ECs, their progenitors from both APB and CB sources are demonstrating immunoregulatory properties. This function was more accentuated for CB-EPCs compared to APB-EPCs making them a perfect choice for cell therapy of cardiovascular disorders, tissue engineering, bio-artificial organs and organ on chips manufacturing. Our results reveal for the first time a mechanism that EPCs use to suppress immune cells. Through different in-vitro experimental approaches, we have blocked TNF $\alpha / T N F R 2$ signaling pathway and showed the importance of this immune checkpoint axis in EPC immunoregulatroy function such as production of different anti-inflammatory cytokines like IL-10, TGF $\beta$ and HLA-G. Altogether, we believe that targeting TNFR2 using its proper antagonist is an effective way for cancer treatment, since not only it efficiently controls immunosuppression by EPCs and other TNFR2 ${ }^{+}$immunosuppressive cells but also tumor angiogenesis and survival. Inversely, administration of TNFR2 agonist could boost EPC immunoregulatroy function in cases like transplantation that increased immunosuppression and angiogenesis are especially crucial.

\section{Supplementary information}

Supplementary information accompanies this paper at https://doi.org/10. 1186/s12964-020-00564-3.

Additional file 1: Supplementary Figure 1. Flow cytometry

representative of proliferation assay. Supplementary Figure 2. ECFCs can modulate $\mathrm{CD}^{+} \mathrm{T}$ cell activation markers. Supplementary Figure $\mathbf{3}$. ECFCs can modulate CD $8^{+} T$ cell activation markers. Supplementary Figure 4. ECFCs immunosuppressive effect is entirely abolished when $T$ 
cells are incapable of TNFa production. Supplementary Figure $\mathbf{5}$ Expression of TNFR1 and TNFR2 on different endothelial cells.

\section{Abbreviations}

APB: Adult Peripheral Blood; B reg: Regulatory B cell; bFGF: Basic Fibroblast Growth Factor; CB: Cord Blood; CFSE: Carboxyfluorescein succinimidyl ester; (CFU-ECs): Colony Forming Unit-Endothelial Cells; ECFCs: Endothelial Colony Forming Cells; ECs: Endothelial Cells; EPCs: Endothelial Progenitor Cells; HAECs: Human Aortic Endothelial Cells; ICOS: Inducible Co-Stimulatory molecule; mAB: Monoclonal Anti Body; MACS: Magnetic-Activated Cell Sorting; MDCSs: Myeloid Derived Suppressive Cells; MFI: Mean Fluorescence Intensity; MNC: Mononuclear cells; MSCs: Mesenchymal Stem Cells; P: Passage; T conv: Conventional T cell; T eff: Effector T cell; T reg: Regulatory T cell; Tc: Cytotoxic T cells; Th: T helper Cells; TNFR1: Tumor Necrosis Factor Receptor 1; TNFR2: Tumor Necrosis Factor Receptor 2; TNFa: Tumor Necrosis Factor alpha; VEGF: Vascular Endothelial Growth Factor; VEGFR2: Vascular Endothelial Growth Factor Receptor 2

\section{Acknowledgements}

Not applicable.

\section{Authors' contributions}

S.N., J.L.C., B.L.S., and G.U. conceived the study. S.N. and G.U., wrote the manuscript; S.N., M.E.A., M.A.B, N.A., G.H., performed experiments; and S.N, M.E.A., M.A.B. analyzed the data. All authors read and approved the final manuscript.

\section{Funding}

This work was supported by a governmental grant via "I'Agence Nationale de la Recherche" in the form of "programme d'Investissements d'avenir" with the grand number: ANR_15-RHUS60002.

\section{Availability of data and materials}

The datasets used and/or analysed during the current study are available from the corresponding author on reasonable request.

\section{Ethics approval and consent to participate}

CB samples were obtained from the CB Bank of St Louis Hospital (Paris, France) authorized by the French Regulatory Authority (no. PPC51). Human APB was obtained from the French Establishment of Blood (EFS, authorization 14/5/011). Legal age to give blood ranges from 18 to 70 years. This activity was declared to and authorized by the French Ministry of Research under number AC- 2008-376, and to the French Organization for standardization under number 201/51848.1.

\section{Consent for publication}

Not applicable.

\section{Competing interests}

The authors declare that they have no competing interests.

\section{Author details}

'INSERM UMR-S-MD 1197, Hôpital Paul Brousse, Villejuif, France. ${ }^{2}$ CellMedEx Saint Maur Des Fossés, France. ${ }^{3}$ Paris-Saclay University, Villejuif, France. ${ }^{4}$ Biochemistry Division, Chemistry department, Faculty of Science, Helwan University, Cairo, Egypt. ${ }^{5}$ Univ Paris Est Creteil, INSERM, IMRB, F-94010 Creteil, France. ${ }^{6} \mathrm{AP}-\mathrm{HP}$, Hopital Henri Mondor, Centre d'investigation clinique biothérapie, F-94010 Creteil, France. 'Sorbonne Université, INSERM, CNRS, Centre d'Immunologie et des Maladies Infectieuses (CIMI-Paris), Paris, France.

Received: 29 January 2020 Accepted: 23 March 2020

Published online: 16 June 2020

\section{References}

1. Asahara T, Murohara T, Sullivan A, et al. Isolation of putative progenitor endothelial cells for angiogenesis. Science. 1997;275(5302):964-7.

2. Masuda $\mathrm{H}$, Asahara T. Post-natal endothelial progenitor cells for neovascularization in tissue regeneration. Cardiovasc Res. 2003;58(2):390-8

3. Wang T, Fang X, Yin Z-S. Endothelial progenitor cell-conditioned medium promotes angiogenesis and is neuroprotective after spinal cord injury.
Neural Regen Res. 2018;13(5):887-95 https://doi.org/10.4103/1673-5374. 232484.

4. Takahashi T, Kalka C, Masuda H, et al. Ischemia- and cytokine-induced mobilization of bone marrow-derived endothelial progenitor cells for neovascularization. Nat Med. 1999;5(4):434-8 https://doi.org/10.1038/7434.

5. Walter DH, Rittig K, Bahlmann FH, et al. Statin therapy accelerates reendothelialization: a novel effect involving mobilization and incorporation of bone marrow-derived endothelial progenitor cells. Circulation. 2002; 105(25):3017-24.

6. Yoder MC, Mead LE, Prater D, Krier TR, Mroueh KN, Li F, Krasich R, Temm CJ, Prchal JT, Ingram DA. Redefining endothelial progenitor cells via clonal analysis and hematopoietic stem/progenitor cell principals. Blood. 2006; 109(5):1801-9.

7. Yoder MC, Mead LE, Prater D, et al. Redefining endothelial progenitor cells via clonal analysis and hematopoietic stem/progenitor cell principals. Blood. 2007;109(5):1801-9 https://doi.org/10.1182/blood-2006-08-043471.

8. Sieveking DP, Buckle A, Celermajer DS, Ng MKC. Strikingly different angiogenic properties of endothelial progenitor cell subpopulations: insights from a novel human angiogenesis assay. J Am Coll Cardiol. 2008; 51(6):660-8 https://doi.org/10.1016/j.jacc.2007.09.059.

9. Au P, Daheron LM, Duda DG, et al. Differential in vivo potential of endothelial progenitor cells from human umbilical cord blood and adult peripheral blood to form functional long-lasting vessels. Blood. 2008;111(3): 1302-5 https://doi.org/10.1182/blood-2007-06-094318.

10. Pearson JD. Endothelial progenitor cells--an evolving story. Microvasc Res. 2010;79(3):162-8 https://doi.org/10.1016/j.mvr.2009.12.004.

11. Uzan G, Vanneaux V, Delmau C, Ayoubi F, Gluckman E, Larghero J. Cord blood circulating endothelial progenitors: perspectives for clinical use in cardiovascular diseases. Bull Acad Natl Med. 2009;193(3):537-43 discussion 543-544.

12. Ferratge S, Ha G, Carpentier G, et al. Initial clonogenic potential of human endothelial progenitor cells is predictive of their further properties and establishes a functional hierarchy related to immaturity. Stem Cell Res. 2017; 21:148-59 https://doi.org/10.1016/j.scr.2017.04.009.

13. Boyer-Di Ponio J, El-Ayoubi F, Glacial F, et al. Instruction of circulating endothelial progenitors in vitro towards specialized blood-brain barrier and arterial phenotypes. PLoS One. 2014;9(1):e84179 https://doi.org/10.1371/ journal.pone.0084179.

14. Prisco AR, Hoffmann BR, Kaczorowski CC, et al. Tumor necrosis factor a regulates endothelial progenitor cell migration via CADM1 and NF-kB. Stem Cells Dayt Ohio. 2016;34(7):1922-33 https://doi.org/10.1002/stem.2339.

15. Leibovich SJ, Polverini PJ, Shepard HM, Wiseman DM, Shively V, Nuseir N. Macrophage-induced angiogenesis is mediated by tumour necrosis factoralpha. Nature. 1987;329(6140):630-2 https://doi.org/10.1038/329630a0.

16. Sato N, Fukuda K, Nariuchi H, Sagara N. Tumor necrosis factor inhibiting angiogenesis in vitro. J Natl Cancer Inst. 1987;79(6):1383-91.

17. Fràter-Schröder M, Risau W, Hallmann R, Gautschi P, Böhlen P. Tumor necrosis factor type alpha, a potent inhibitor of endothelial cell growth in vitro, is angiogenic in vivo. Proc Natl Acad Sci U S A. 1987;84(15):5277-81 https://doi.org/10.1073/pnas.84.15.5277.

18. Fajardo LF, Kwan HH, Kowalski J, Prionas SD, Allison AC. Dual role of tumor necrosis factor-alpha in angiogenesis. Am J Pathol. 1992;140(3):539-44.

19. Salomon BL, Leclerc M, Tosello J, Ronin E, Piaggio E, Cohen JL. Tumor necrosis factor a and regulatory $T$ cells in oncoimmunology. Front Immunol. 2018:9:444 https://doi.org/10.3389/fimmu.2018.00444.

20. Yang S, Wang J, Brand DD, Zheng SG. Role of TNF-TNF receptor 2 signal in regulatory T cells and its therapeutic implications. Front Immunol. 2018;9: 784 https://doi.org/10.3389/fimmu.2018.00784

21. Yan $\mathrm{L}$, Zheng $\mathrm{D}, \mathrm{Xu} \mathrm{R}-\mathrm{H}$. Critical role of tumor necrosis factor signaling in mesenchymal stem cell-based therapy for autoimmune and inflammatory diseases. Front Immunol. 2018:9:1658 https://doi.org/10.3389/fimmu.2018. 01658.

22. Yoshida S, Ono M, Shono T, et al. Involvement of interleukin-8, vascular endothelial growth factor, and basic fibroblast growth factor in tumor necrosis factor alpha-dependent angiogenesis. Mol Cell Biol. 1997;17(7): 4015-23 https://doi.org/10.1128/mcb.17.7.4015.

23. Krönke $M$, Schütze $S$, Scheurich $P$, Pfizenmaier $K$. TNF signal transduction and TNF-responsive genes. Immunol Ser. 1992;56:189-216.

24. Hoefer IE, van Royen N, Rectenwald JE, et al. Direct evidence for tumor necrosis factor-alpha signaling in arteriogenesis. Circulation. 2002;105(14): 1639-41 https://doi.org/10.1161/01.cir.0000014987.32865.8e. 
25. Monden $Y$, Kubota $T$, Inoue $T$, et al. Tumor necrosis factor-alpha is toxic via receptor 1 and protective via receptor 2 in a murine model of myocardial infarction. Am J Physiol Heart Circ Physiol. 2007;293(1):H743-53 https://doi. org/10.1152/ajpheart.00166.2007.

26. Zhang Y, Zhao J, Lau WB, et al. Tumor necrosis factor-a and lymphotoxin-a mediate myocardial ischemic injury via TNF receptor 1 , but are cardioprotective when activating TNF receptor 2. PLoS One. 2013;8(5): e60227 https://doi.org/10.1371/journal.pone.0060227.

27. Kishore R, Tkebuchava T, Sasi SP, et al. Tumor necrosis factor-a signaling via TNFR1/p55 is deleterious whereas TNFR2/p75 signaling is protective in adult infarct myocardium. Adv Exp Med Biol. 2011;691:433-48 https://doi.org/10. 1007/978-1-4419-6612-4_45.

28. Katare RG, Ando M, Kakinuma Y, Arikawa M, Yamasaki F, Sato T. Differential regulation of TNF receptors by vagal nerve stimulation protects heart against acute ischemic injury. J Mol Cell Cardiol. 2010;49(2):234-44 https:// doi.org/10.1016/j.yjmcc.2010.03.007.

29. Aggarwal S, Gollapudi S, Gupta S. Increased TNF-alpha-induced apoptosis in lymphocytes from aged humans: changes in TNF-alpha receptor expression and activation of caspases. J Immunol Baltim Md 1950. 1999;162(4):2154-61.

30. Goukassian DA, Qin G, Dolan C, et al. Tumor necrosis factor-alpha receptor p75 is required in ischemia-induced neovascularization. Circulation. 2007; 115(6):752-62 https://doi.org/10.1161/CIRCULATIONAHA.106.647255.

31. Luo $Y, X u Z$, Wan $T$, et al. Endothelial-specific transgenesis of TNFR2 promotes adaptive arteriogenesis and angiogenesis. Arterioscler Thromb Vasc Biol. 2010;30(7):1307-14 https://doi.org/10.1161/ATVBAHA.110.204222

32. Naserian S, Abdelgawad ME, Lachaux J, et al. Development of Bio-Artificial Micro-Vessels with Immunosuppressive Capacities: A Hope for Future Transplantations and Organoids. Blood. 2019;134(Supplement_1):3610 https://doi.org/10.1182/blood-2019-121395.

33. Proust $R$, Ponsen AC, Rouffiac V, Schenowitz C, Montespan F, Ser-Le Roux K, De Leeuw F, Laplace-Builhe C, Mauduit P, Carosella ED, Banzet S, Lataillade JJ, Rouas-Freiss N, Uzan G, Peltzer J. Cord bloodendothelial colony forming cells are immunotolerated and participate at post-ischemic angiogenesis in an original dorsal chamber immunocompetent mouse model. Stem Cell Res Ther. 2020;11(1).

34. Polz J, Remke A, Weber $\mathrm{S}$, et al. Myeloid suppressor cells require membrane TNFR2 expression for suppressive activity. Immun Inflamm Dis. 2014;2(2): 121-30 https://doi.org/10.1002/iid3.19.

35. Leclerc M, Naserian S, Pilon C, et al. Control of GVHD by regulatory T cells depends on TNF produced by T cells and TNFR2 expressed by regulatory $T$ cells. Blood. 2016;128(12):1651-9 https://doi.org/10.1182/blood-2016-02700849

36. Ticha O, Moos L, Wajant H, Bekeredjian-Ding I. Expression of tumor necrosis factor receptor 2 characterizes TLR9-driven formation of interleukin-10producing B cells. Front Immunol. 2017;8:1951 https://doi.org/10.3389/ fimmu.2017.01951

37. Marino J, Paster J, Benichou G. Allorecognition by T lymphocytes and allograft rejection. Front Immunol. 2016;7:582 https://doi.org/10.3389/fimmu.2016.00582.

38. Singh B, Read S, Asseman C, et al. Control of intestinal inflammation by regulatory T cells. Immunol Rev. 2001;182:190-200.

39. Reddy M, Eirikis E, Davis C, Davis HM, Prabhakar U. Comparative analysis of lymphocyte activation marker expression and cytokine secretion profile in stimulated human peripheral blood mononuclear cell cultures: an in vitro model to monitor cellular immune function. J Immunol Methods. 2004; 293(1-2):127-42 https://doi.org/10.1016/j.jim.2004.07.006.

40. Dong C, Juedes AE, Temann UA, et al. ICOS co-stimulatory receptor is essential for T-cell activation and function. Nature. 2001;409(6816):97-101 https://doi.org/10.1038/35051100.

41. Hu X, Li B, Li X, et al. Transmembrane TNF-a promotes suppressive activities of myeloid-derived suppressor cells via TNFR2. J Immunol Baltim Md 1950. 2014;192(3):1320-31 https://doi.org/10.4049/jimmunol.1203195.

42. Kanamaru F, Youngnak $P$, Hashiguchi $M$, et al. Costimulation via glucocorticoid-induced TNF receptor in both conventional and CD25+ regulatory CD4+ T cells. J Immunol Baltim Md 1950. 2004;172(12):7306-14.

43. Chen X, Hamano R, Subleski JJ, Hurwitz AA, Howard OMZ, Oppenheim JJ. Expression of costimulatory TNFR2 induces resistance of CD4+FoxP3conventional T cells to suppression by CD4+FoxP3+ regulatory T cells. J Immunol Baltim Md 1950. 2010;185(1):174-82 https://doi.org/10.4049/ jimmunol.0903548

44. Induction of CD4+CD25+FOXP3+ regulatory T cells by mesenchymal stem cells is associated with modulation of ubiquitination factors and TSDR demethyl... - PubMed - NCBI. https://www-ncbi-nlm-nih-gov.proxy. insermbiblio.inist.fr/pubmed/30359308. Accessed 23 Nov 2019.

45. Mesenchymal stem cells can induce regulatory T cells via modulating miR126a but not miR-10a. - PubMed - NCBI. https://www-ncbi-nlm-nih-gov. proxy.insermbiblio.inist.fr/pubmed/28600182. Accessed 23 Nov 2019.

46. Khosravi M, Bidmeshkipour A, Moravej A, Hojjat-Assari S, Naserian S, Karimi $\mathrm{MH}$. Induction of CD4+CD25+Foxp3+ regulatory T cells by mesenchymal stem cells is associated with RUNX complex factors. Immunol Res. 2018; 66(1):207-18 https://doi.org/10.1007/s12026-017-8973-4.

47. Drukker M, Katchman H, Katz G, et al. Human embryonic stem cells and their differentiated derivatives are less susceptible to immune rejection than adult cells. Stem Cells Dayt Ohio. 2006;24(2):221-9 https://doi.org/10.1634/ stemcells.2005-0188.

48. Grinberg-Bleyer Y, Saadoun D, Baeyens A, et al. Pathogenic T cells have a paradoxical protective effect in murine autoimmune diabetes by boosting Tregs. J Clin Invest. 2010;120(12):4558-68 https://doi.org/10.1172/JCl42945.

49. Baeyens A, Saadoun D, Billiard F, et al. Effector $T$ cells boost regulatory $T$ cell expansion by IL-2, TNF, OX40, and plasmacytoid dendritic cells depending on the immune context. J Immunol Baltim Md 1950. 2015;194(3):999-1010 https://doi.org/10.4049/jimmunol.1400504

50. Naserian S, Leclerc $M$, Thiolat $A$, et al. Simple, reproducible, and efficient clinical grading system for murine models of acute graft-versus-host disease. Front Immunol. 2018;9:10 https://doi.org/10.3389/fimmu.2018.00010.

51. Green LA, Njoku V, Mund J, et al. Endogenous Transmembrane TNF-alpha protects against premature senescence in endothelial Colony forming cells. Circ Res. 2016;118(10):1512-24 https://doi.org/10.1161/CIRCRESAHA.116. 308332.

52. Buzzi M, Alviano F, Campioni D, et al. Umbilical cord blood CD34(+)cellderived progeny produces human leukocyte antigen-G molecules with immuno-modulatory functions. Hum Immunol. 2012;73(2):150-5 https://doi. org/10.1016/j.humimm.2011.12.003.

53. Yang H-M, Song W-J, Li Q, et al. Canine mesenchymal stem cells treated with TNF- $a$ and IFN- $\gamma$ enhance anti-inflammatory effects through the COX2/PGE2 pathway. Res Vet Sci. 2018;119:19-26 https://doi.org/10.1016/j.rvsc. 2018.05.011.

54. Pierini A, Strober W, Moffett C, et al. TNF-a priming enhances CD4+FoxP3+ regulatory T-cell suppressive function in murine GVHD prevention and treatment. Blood. 2016;128(6):866-71 https://doi.org/10.1182/blood-2016-04711275 .

55. Kim DS, Jang IK, Lee MW, et al. Enhanced immunosuppressive properties of human mesenchymal stem cells primed by interferon- $\gamma$. EBioMedicine. 2018; 28:261-73 https://doi.org/10.1016/j.ebiom.2018.01.002.

56. Redondo-Castro E, Cunningham C, Miller J, et al. Interleukin-1 primes human mesenchymal stem cells towards an anti-inflammatory and protrophic phenotype in vitro. Stem Cell Res Ther. 2017;8(1):79 https://doi.org/ 10.1186/s13287-017-0531-4.

57. de la Puente P, Muz B, Azab F, Azab AK. Cell trafficking of endothelial progenitor cells in tumor progression. Clin Cancer Res Off J Am Assoc Cancer Res. 2013;19(13):3360-8 https://doi.org/10.1158/1078-0432.CCR-130462.

58. Zuazo-Gaztelu I, Casanovas O. Unraveling the role of angiogenesis in cancer ecosystems. Front Oncol. 2018:8:248 https://doi.org/10.3389/fonc.2018. 00248.

59. Zhao X, Liu H-Q, Li J, Liu X-L. Endothelial progenitor cells promote tumor growth and progression by enhancing new vessel formation. Oncol Lett. 2016;12(2):793-9 https://doi.org/10.3892/ol.2016.4733.

60. Marçola M, Rodrigues CE. Endothelial progenitor cells in tumor angiogenesis: another brick in the wall. Stem Cells Int. 2015;2015:832649 https://doi.org/10.1155/2015/832649.

61. Torrey H, Butterworth J, Mera T, et al. Targeting TNFR2 with antagonistic antibodies inhibits proliferation of ovarian cancer cells and tumor-associated Tregs. Sci Signal. 2017;10:462 https://doi.org/10.1126/scisignal.aaf8608.

62. Torrey $\mathrm{H}$, Khodadoust $M$, Tran $L$, et al. Targeted killing of TNFR2-expressing tumor cells and Tregs by TNFR2 antagonistic antibodies in advanced Sézary syndrome. Leukemia. 2019;33(5):1206-18 https://doi.org/10.1038/s41375018-0292-9.

\section{Publisher's Note}

Springer Nature remains neutral with regard to jurisdictional claims in published maps and institutional affiliations. 